University of Rhode Island

DigitalCommons@URI

Open Access Master's Theses

2017

\title{
The Continuum of Beach Enclosure: Socioeconomic Implications for Coastal Communities in the Dominican Republic
}

Melvin Alvarez

University of Rhode Island, melvin_alvarez@uri.edu

Follow this and additional works at: https://digitalcommons.uri.edu/theses

\section{Recommended Citation}

Alvarez, Melvin, "The Continuum of Beach Enclosure: Socioeconomic Implications for Coastal Communities in the Dominican Republic" (2017). Open Access Master's Theses. Paper 1140.

https://digitalcommons.uri.edu/theses/1140

This Thesis is brought to you for free and open access by DigitalCommons@URI. It has been accepted for inclusion in Open Access Master's Theses by an authorized administrator of DigitalCommons@URI. For more information, please contact digitalcommons-group@uri.edu. 
THE CONTINUUM OF BEACH ENCLOSURE: SOCIOECONOMIC IMPLICATIONS FOR COASTAL COMMUNITIES IN THE DOMINICAN REPUBLIC

BY

MELVIN ALVAREZ

A THESIS SUBMITTED IN THE PARTIAL FULFILLMENT OF THE REQUIREMENTS FOR THE DEGREE OF MASTER OF ARTS

IN

MARINE AFFAIRS

UNIVERSITY OF RHODE ISLAND

2017 
MASTER OF ARTS THESIS

OF

MELVIN ALVAREZ

APPROVED:

Thesis Committee:

Major Professor Robert Thompson

Carlos Garcia-Quijano

Rosaria Pisa

Nasser H. Zawia

DEAN OF THE GRADUATE SCHOOL

UNIVERSITY OF RHODE ISLAND

2017 


\section{Abstract:}

Unprecedented proliferation in tourism and coastal development in the Dominican Republic (DR) has transformed the shoreline into a site of conflict as the public and traditional users lose access to the shore. This case study research, based on ethnography and interview data, explores the processes leading to beach privatization and how the Continuum of Beach Enclosure (CBE) affects the socioeconomic structure of local communities and entrepreneurs. Global trends in enclosure of the common are combined with Tourism Area Life Cycle (TALC) model to highlight coastal development in the context of DR. The study concludes that different forms of capital (social, economic, or political) are predominant at various stages of development to generate enclosed spaces with an array of community impacts at each stage.

Key words: enclosure; beach access; tourism area life cycle (TALC); community development 


\section{Acknowledgements:}

This research project was completed thanks to the support of various contributing parties. Thank you, Dr. Robert Thompson, my advisor, for the guidance and feedback you provided in developing and conducting this project. I am also grateful to my committee members, Dr. Carlos Garcia-Quijano and Rosaria Pisa, for their evaluation and feedback. I would also like to thank my defense chair, Dr. Austin Humphries. Thanks to the Global Foundation for Democracy and Development for providing the funding needed to conduct this research in the Dominican Republic, as well as their personnel for their support

during field research. A special thanks to Dr. Yolanda Leon for her great support while in the Dominican Republic. I would also like to thank some of my peers and dear friends for the encouragement and insightful comments. Thanks to all research participants and other wonderful people in Samaná that made this project a reality through their contribution, hospitality, and willingness to help.

Especial thanks to my parents, Daisi and Julio, for their support and immeasurable sacrifices. I would have not done this without you. Gracias! 


\section{Preface:}

This thesis was written in manuscript form because it will be submitted to the Annals of Tourism Research journal. All pages and sections have been formatted in accordance with the journal guidance. 


\section{TABLE OF CONTENTS}

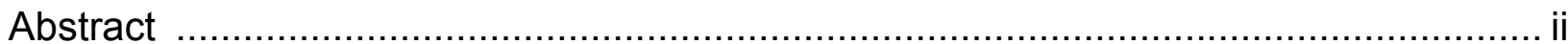

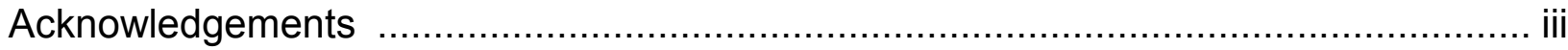

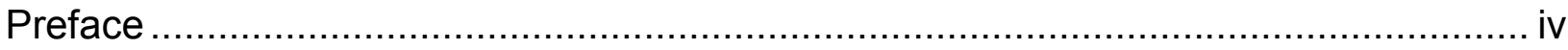

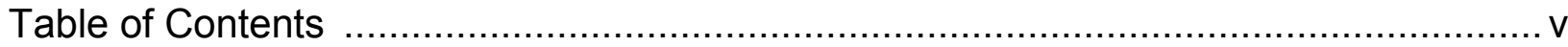

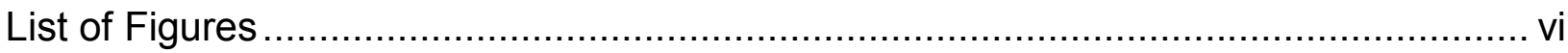

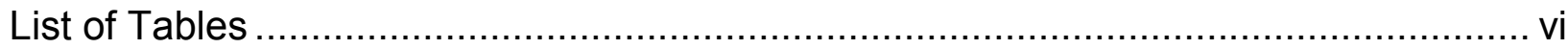

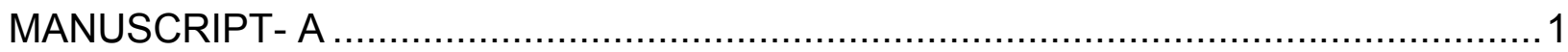

INTRODUCTION

Overview of Tourism in the Dominican Republic ................................................ 4

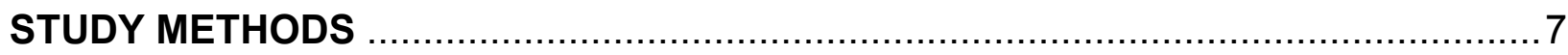

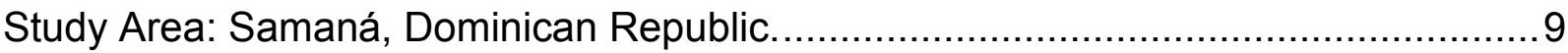

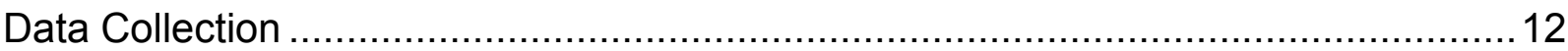

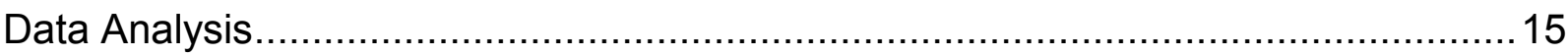

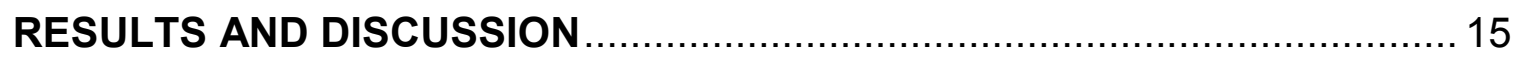

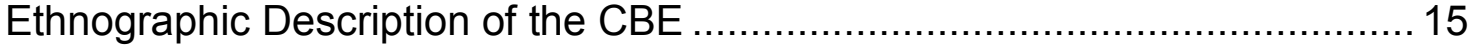

The CBE and Effects on Coastal Communities: Initial Five Stages ................ 19

The CBE, Different Forms of Capital, and the Last Three Stages .................. 24

The CBE: Resorts Impacts on the Community ......................................... 35

Addressing Power Imbalances Via Community Referenda ........................... 39

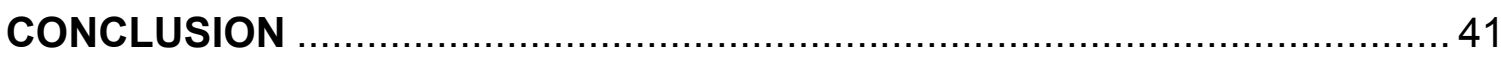

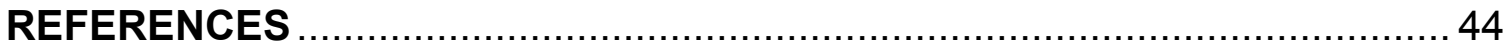




\section{List of Figures:}

Figure 1. The Continuum of Beach Enclosure and Different Stages of

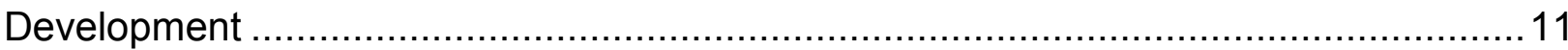

Figure 2. Business and Asociaciones on Playa Rincon and Playa Grande Samaná, Dominican Republic ........................................................................... 13 


\section{List of Tables:}

Table 1: List of Interviewed Participants 


\title{
MANUSCRIPT- A
}

To be submitted for publication in Annals of Tourism Research.

\section{The Continuum of Beach Enclosure: Socioeconomic Implications for Coastal Communities in the Dominican Republic}

\author{
Melvin Alvarez, Robert Thompson, Carlos Garcia-Quijano \\ Department of Marine Affairs, University of Rhode Island \\ Corresponding Author: Melvin Alvarez \\ Department of Marine Affairs \\ University of Rhode Island \\ 206, Coastal Institute, 1 Greenhouse Road \\ Kingston, RI 02881, USA \\ Phone: (703)-944-9775 \\ Email: Melvin_alvarez@uri.edu
}




\section{INTRODUCTION}

The people of the Dominican Republic (DR) have a constitutional right to access the ocean shoreline (Dominican Republic Const. art. XV) and the shoreline provides an important setting for many aspects of community life. The Dominican shore often functions as a commons for socializing, subsistence, and other economic activity (Cabezas, 2008). However, increases in tourism and coastal development can often lead to conflicts over shoreline access between traditional users of the coastline and the newcomers. In the last six years, tourism has expanded rapidly with an annual growth of four percent per year globally and at a rate exceeding seven percent in the Caribbean (World Tourism Organization, 2016). Caribbean Tourism Organization (2015) data places the Dominican Republic as the number one destination in the region with over 5.14 million tourist visits in 2014. This fast growth in tourism has transformed much of the coastline into a site for private development and, hence, a site for conflict as members of the public lose access to the shore. News coverage demonstrates that this is a global phenomenon with, for example, reported cases in Greece, Cyprus, Italy, Lebanon, and the DR, where private enterprises have either attempted or succeeded at obtaining exclusive private rights to the shoreline

Melvin Alvarez (alvarez.melvin11@gmail.com) is completing a MA in Marine Affairs at the University of Rhode Island, USA. He holds a dual BA in Environmental Studies and Spanish Literature from Skidmore College, New York, USA. Melvin is of Honduran descent and maintains an interest in studying the community perspective on development in the Global South. 
despite objections from local communities (di Gianfrancesco, 2014; Hadjimichael, 2014; Reclaim the Sea, 2014a; Reclaim the Sea, 2014b; Molina, 2006). Scientific literature has also emphasized the growing trend of privatization (also known as enclosure) and dispossession of common space in rural areas, cities, and beaches (Borras, Franco, Gómez, Kay, \& Spoor, 2017; Brown, 2006; Keul, 2015; Sevilla-Buitrago, 2015; Syafriny, 2015; Van Noorloos, 2011).

Coastal privatization and development in the DR is occurring at an unprecedented rate (León, 2007), expanding to many new regions of the country and threatening to alter many Dominicans' way of life and the public's relationship to the shoreline (Skoczen, 2008). Studies regarding privatization and tourism development in the DR typically focus on large projects with substantial influxes of foreign capital and complete or near-complete enclosure (e.g., Pardilla Pino \& Navarro Barber, 2014; Sasidharan \& Hall, 2012; Roessingh \& Duijnhoven, 2005), despite the fact that the privatization of public space occurs at many scales (from small owner/operators to large international destinations) and along a continuum from weak to absolute enclosure (Sevilla-Buitrago, 2015). This Continuum of Beach Enclosure (CBE) refers to the notion that, despite the law, beaches along the Dominican shoreline all fall somewhere along a continuum from completely open to the public to completely closed, e.g., completely controlled by the private tourism enterprise. Because moments where open access beaches are potentially converting to closed access create a sudden increase in grievances and often organized opposition (Keul, 2015; Van Noorloos, 2011), attention to this type of conflict should not be surprising. 
Nonetheless, this focus provides only a partial understanding because it fails to capture the different levels of beach enclosure and the implication for coastal communities at each stage. In the presented case study, researchers aim to provide an insight into the CBE and its different stages.

\section{Overview of Tourism in the Dominican Republic}

Despite being among the late Caribbean countries to join the tourism industry, the DR has surpassed many competitors (e.g., Cuba and Bahamas) and solidified itself as one of the top destinations in the region (Duffy, Stone, \& Chancellor, 2016; World Tourism Organization, 2016). Prior to 1967 the tourism industry in the country was almost non-existent (Freitag, 1996). In 1967 the Dominican government created the Ministry of Tourism to promote and manage the development of a tourism industry (Freitag, 1996). In 1971 the Dominican government introduced the "Tourism Incentive Law" offering tax breaks and a variety of incentives for private investors in tourism (Freitag, 1996, p. 231). Through a series of presidential decrees in the 1970s, five designated tourism zones were established, including Samaná (Freitag, 1996; Leon, 2004). To finance and support the development of essential infrastructure in the country's designated tourism zones, the Dominican government created an organization called INFRATUR (El Desarrollo de la Infraestructura Turistica) (Freitag, 1996; Leon, 2004). The public and mostly foreign private investment in tourism received strong political support in the early years of pro-tourism reforms from the Dominican government that created new agencies and tax break in favor of the industry. 
By the late 1980s, tourism had become a well-established and fastgrowing industry in the DR. In 1983, the country had only 4,000 hotel rooms, but in 1995 the number of rooms exceeded 28,000 (Freitag, 1996). By 2002, hotel capacity in the country had grown to 55,000 rooms (León, 2007) and by 2011 there were 66,790 hotel rooms (Duffy et al., 2016). The rapid growth in hotel capacity in the last three decades corresponds with the steady growth of international tourist arrivals. World Bank data shows an average nine percent annual growth in tourist arrivals in the DR between 1993 and 2002 (Duffy et al., 2016). This data also reveals an increase from $3,282,000$ visits in 2003 to 4,125,000 visits in 2010 (Duffy et al., 2016) and 5,141,377 visitors in 2014 (Caribbean Tourism Organization, 2015) The success of the tourism industry has propelled the DR into an upper-middle-income country and transformed the island nation into one of the largest economies in the Caribbean ( Duffy et al., 2016; Caffrey et al., 2013).

This apparent success in national development of tourism is attributed to the variety of economic and political reforms in favor of neoliberalism that have taken place since the 1970s. A total of 38 World Bank agreements between 1970 and 2004; six International Monetary Funds between 1982 and 2005; various free trade agreements; and several USAID, Inter-American Development Bank, and UN Development Programme projects have created an atmosphere that leverages the interests of multinational investors (see Mitchell, 2009). Duffy et al. (2016) argue that structural adjustment policies undertaken by the government 
forced the DR to put its economy, politics, and citizens at the mercy of foreignowned, large-scale tourism development. The researchers assert:

As a condition to secure international loans from agencies such as the International Monetary Fund and World Bank, the DR was required to open its borders to international trading, lifting trade barriers and governmental controls, and implementing new economic policies that encouraged further globalization (Duffy et al., 2016, p. 3).

While this approach has created a strong tourism industry, the nature of this industry is mass resort tourism, which despite generating significant economic leakage to foreign investors, produces substantial taxable income for the national government (Freitag, 1996; Mitchell, 2009; Roessingh \& Duijnhoven, 2005). As the national government and elites enjoy the economic benefits of tourism, regionally many communities embracing tourism are still waiting the promised benefits from the industry (Freitag, 1996; Roessingh \& Duijnhoven, 2005). The approach to tourism development in favor of national and foreign income generation has resulted in a sizable unequal distribution of wealth, as well as entire communities marginalized by the current methods of resort tourism development in the DR (Caffrey et al., 2013; Freitag, 1996; León, 2007;

Roessingh \& Duijnhoven, 2005; Sasidharan \& Hall, 2012). Other studies have underlined issues of inflation, environmental destruction, lost of community, increase in crime, drugs, prostitution, and other social issues. Freitag (1994; 1996) studies of resort development in the northeastern region of the DR showed substantial negative impacts from international tourism development, including environmental degradation, lost of community homogeneity, and commodity inflation. A USDA (2012) report's assessment of Samaná concluded that the 
peninsula is unable to provide sufficient infrastructure for trash and wastewater management. These issues observed by USDA in Samaná are also shared with all other regions in the DR also struggling to manage wastewater (Phillips, Russell, \& Turner, 2007). Cabezas's (2008) study addresses the issues of increasing violence, drugs, prostitution, and exclusion and marginalization of a vast portion of the labor force as a result of tourism expansion. Cabeza (2008) referenced the 2005 United Nations Human Development Report for the DR demonstrating that salary for tourism workers are below the national average.

Samaná is among these regions awaiting the promised benefits of tourism. Governmental efforts to transform Samaná into a tourism hub started decades ago (Freitag, 1996). However, the region's tourism industry only start gaining traction and grow by the late 1990s (Leon, 2004). In Samaná, coastal communities are experiencing different levels of development with some areas transforming into seaside European-style villages and others like Rincon at early stages of tourism expansion (Ripton, 2013; Skoczen, 2008; USAID, 2012). Because people's relationship to the shore, their social and economic life changes at different developmental and privatization levels, this study examines the implications of such development along the CBE. The least developed Playa Rincon is contrasted with Playa Grande in a case study to illustrate the progressive nature of coastal enclosure and its effects on communities.

\section{STUDY METHODS}

The reported global occurrence of privatization of common space has 
immediate consequences on people dependent on these commons areas. Sevilla-Buitrago's (2015) analysis of the history of privatization of the public commons to create private, capitalistic ventures helps explain the processes behind the phenomenon where common shorelines are succumbing to the penetration of capital and turning into private business areas. Sevilla-Buitrago (2015) argues that enclosure through capital has become the main mechanism to standardize common spaces through the assistance of national governments in less developed countries. Building on this work, the main research question in this study asked: what are the processes leading to beach privatization and what are the socioeconomic implications for the community at different stages on the continuum of enclosure? This study hypothesized that (1) the primary functions of the beach are for subsistence, recreation, and economic activity; (2) while initial small-scale enclosure requires only minimal financial capital, such enclosure demands substantial social capital; (3) and as enclosure increasing in size and exclusivity it requires considerably more financial capital, and social capital is increasingly replaced by political capital.

The CBE provides a useful model of beach access and enclosure that is well suited to understand the Dominican coast and effects of privatization on communities. Rather than thinking of the shoreline as either completely closed to the public or completely private, these extreme positions can be thought of as end points of a continuum. In between either end, a mixture of private and public shoreline exists with people enclosing parts of the beach for different time periods and various purposes at eight different stages of the continuum (Figure 
1). For example, at stage two of the $\mathrm{CBE}$ the shore is used for artisan fishing boat storage, while in the last two stages local activities and enterprises compete with international resort compex intensifying enclosure (Figure 1). Since the socioeconomic structure of coastal residents is affected at different stages of the $\mathrm{CBE}$, attention to this gradual phenomenon is well overdue.

Butler's (1980) Tourism Area Life Cycle (TALC) model is used complementary to the observed effects of the CBE on Dominican coastal communities. Jointly, these two models illustrate the developmental trajectory of beaches from isolated spaces to crowded and fully developed areas. The six stages of the TALC model continues to be a useful framework for the description and interpretation of the evolution of tourism areas (Butler, 1980, 2011; Hovinen, 2002; Tooman, 1997). The model utilizes the concept of the product lifecycle and through a basic S-curve graph describes the destination life cycle of an area in the consecutive stages of: exploration, involvement, development, consolidation, stagnation, and either rejuvenation or decline (Butler, 1980).

\section{Study Area: Samaná, Dominican Republic.}

This research took place in two coastal communities in the DR: Rincon and Las Galeras (Figure 2). The DR is a Caribbean nation occupying two-thirds of the island of Hispaniola (Heredia, 2009). The World Bank classifies the DR as an upper-middle-income country, however, over 40 percent of the 10 million Dominicans on the island live at or below the poverty line (Caffrey, Kindberg, Stone, Torres, \& Meier, 2013). Poverty is more concentrated in rural areas, such 
as the coastal communities in the studied sites (USAID, 2013).

In Las Galeras, the study took place along Playa Grande beach, which has numerous small-scale economic activity. The east end of Playa Grande contains an all-inclusive resort hotel and spread around town are nine other small hotels or villas (USAID, 2012). The town of Rincon is located west from Las Galeras. Its town beach, Playa Rincon, contains some small-scale economic activity and fishing. Playa Rincon is primarily a daytrip destination, as there are no hotels installations along the coast.

Enterprises on Playa Grande and Playa Rincon are spread out over different sections of the beach, sections that are often controlled by an entrepreneur or group of entrepreneurs on the shore (Figure 2). Although there are many restaurants, bars, shops, and street vendors in town, this study only focuses on economic activity occurring along the beach as it is more relevant to beach access issues. To enhance their network and strengthen their territorial control over a particular part of the beach, enterprises are organized into "asociaciones" or labor unions (Figure 2). Although other studies have described and translated the term asociaciones as labor unions to explain the organization of enterprises into organized groups, the phenomenon would be better interpreted as guilds or cooperatives since these asociaciones often exercise considerable power over the shore. Studies in the DR have documented the use of asociaciones to compete against hotel chains, exert control over the shore, impose restrictions on entrepreneurial operations, and mediate conflicts (Roessingh \& Duijnhoven, 2005; Skoczen, 2008). 


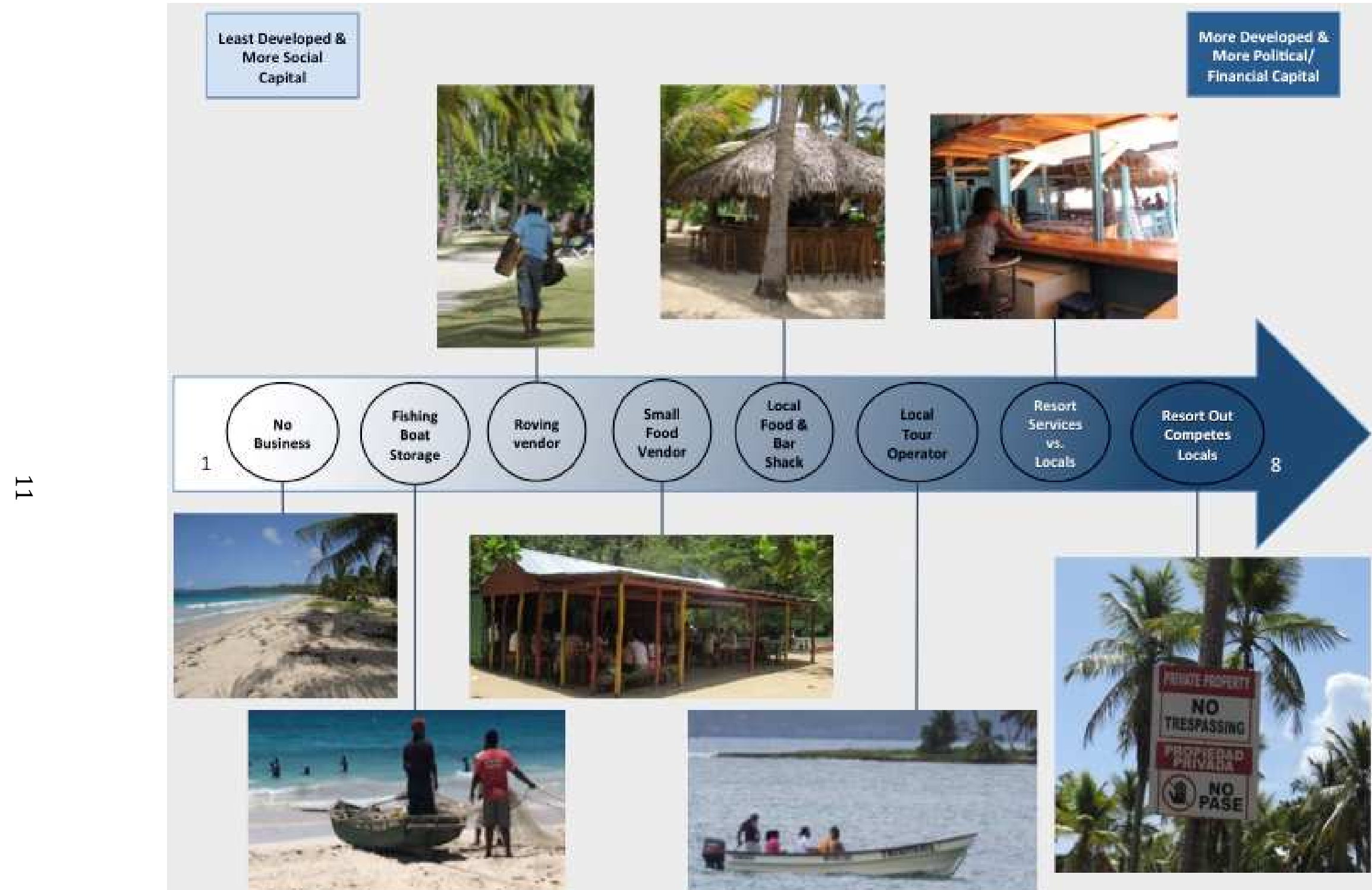

Figure 1. The Continuum of Beach Enclosure and Different Stages of Development 


\section{Data Collection}

Qualitative data was collected in the low tourism season, from June through August 2016. This study utilized a qualitative research approach because of the exploratory nature of the study and the need to provide insight into the reality of a certain group of people (entrepreneurs and their community) within their everyday settings. Ethnography was utilized to obtain a rudimentary understanding of coastal users. Ethnography has been proven essential in other regional studies under similar geographical, cultural, and development levels (García-Quijano, 2009; Roessingh \& Duijnhoven, 2005; Skoczen, 2008). During and immediately after each ethnographic observation or conversation, notes were taken recording the type of social and economic activities observed along the shore, as well as information provided by individuals.

In-depth, semi-structured interviews with coastal users proceeded ethnographic data collection. The interview questionnaire followed a funnel model design, which entails a set of open ended and generic questions, which become more focused as the interview progresses - thus, avoiding leading participants in a particular way early in the process (see Runeson \& Höst, 2009). The questionnaire covered three main topics: the role of the beach for individuals, changes in beach use, and conducting economic activity on the shore. In addition to ethnography, a pilot project implementation at a nearby community with similar attributes and daytrip tourism helped pre-screen, improve, and tailor the interview questionnaire to be more region-specific. 


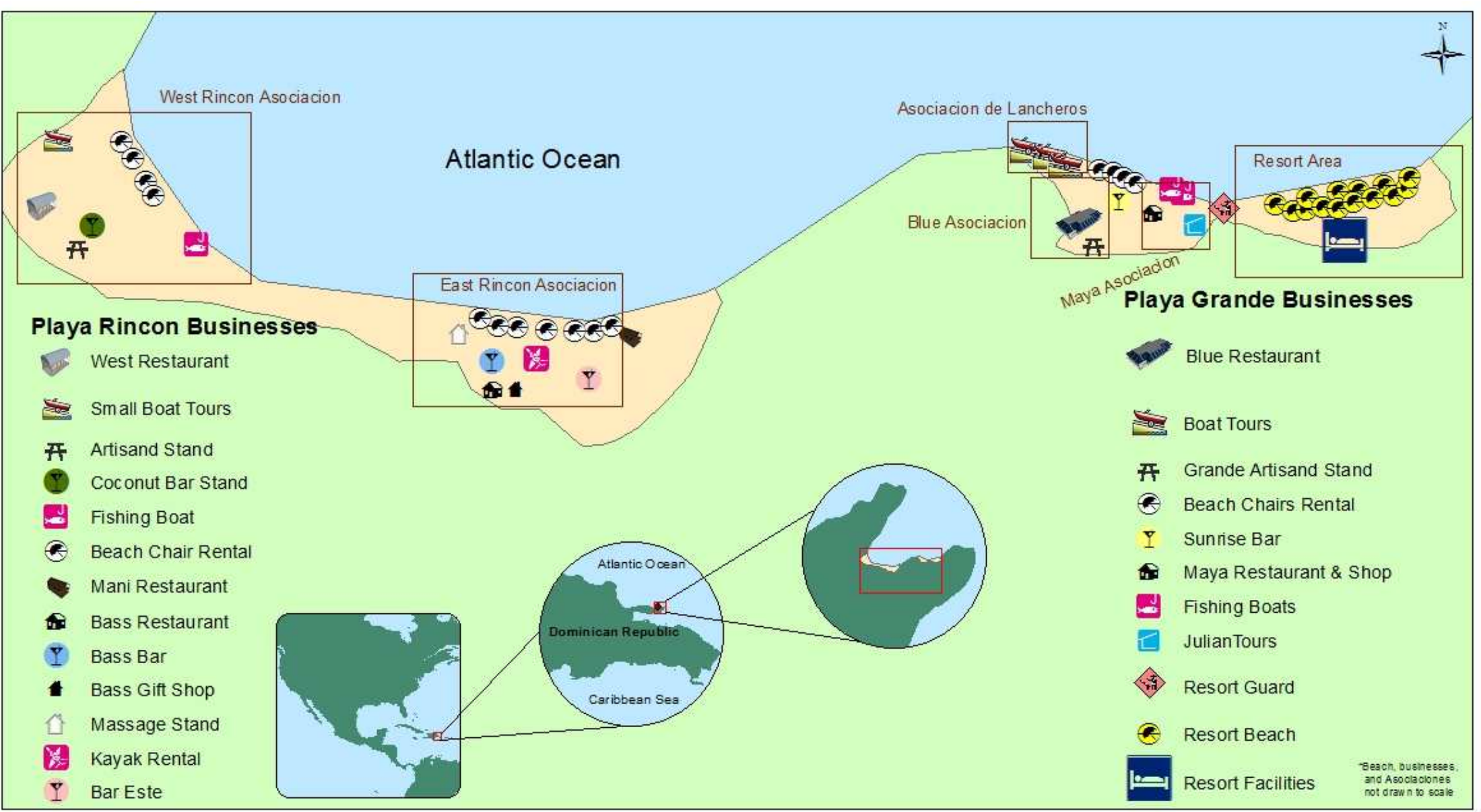

Figure 2. Businesses and Asociaciones on Playa Rincon and Playa Grande Samaná, Dominican Republic 
Interviews with 48 stakeholders were conducted (see Table 1). To guarantee anonymity of interviewees, pseudonyms are used in the writing process. Among the interviewed key informants are 20 entrepreneurs working along the shore, three elected officials, and four community leaders. Key informants are well-connected and informed community experts (Johnson, 1990). Ethnographic research served to identify initial key informants. Snowball sampling technique was subsequently used to identify more key informants until a point of saturation was reached (Bernard, 2011; Johnson, 1990).

Table 1. List of Interviewed Participants

\begin{tabular}{llcc}
\hline Interviewees $(\mathrm{n}=48)$ & Playa Grande & Playa Rincon \\
\hline \multirow{2}{*}{ Key Informants $(\mathrm{n}=27)$} & Entrepreneurs $(\mathrm{n}=20)$ & 9 & 11 \\
& Govn't Officials $(\mathrm{n}=3)$ & 3 & - \\
Locals $(\mathrm{n}=7)$ & Comm. Leaders $(\mathrm{n}=4)$ & 3 & 1 \\
\multirow{2}{*}{ Tourists $(\mathrm{n}=14)$} & Fishers $(\mathrm{n}=5)$ & 3 & 2 \\
& Shoreline Users $(\mathrm{n}=2)$ & 2 & 0 \\
& National $(\mathrm{n}=3)$ & 0 & 3 \\
& International $(\mathrm{n}=10)$ & 8 & 2 \\
\hline
\end{tabular}

To sample all other coastal users, a systematic random sampling technique was employed (Bernard, 2011). Intercepts were conducted along the beach and every third person encountered along a transection line was asked to participate in the study. When a group was encountered, every second individual to the left of the researcher was asked to participate. Almost all interviews with Spanish or English speakers were audio recorded. 


\section{Data Analysis}

Ethnographic data produced extensive notes and were read multiple times. Annotations of recurring observations and themes were made. Bernard (2011) indicates that for preliminary analysis of field notes low-tech methods, such as ocular scan and intraocular percussion test, are ideal.

All interviews were transcribed and a thematic analysis and synthesis of patterns followed (Bernard, 2011) using the NVivo qualitative coding software. Identification and categorization of themes found in transcribed lines and paragraphs were then peerreviewed to ensure balanced and definitive themes. These themes were first coded into large categories or primary nodes that aimed to capture all major emergent themes. Examples of the main primary nodes are "Enclosure," "Beach Use," and "Government." These broad categories subsequently established secondary and tertiary nodes, under the primary node categories. For instance, the node "Enclosure" was further divided into "First-in-time," which was further specified into a tertiary node designated "Associations." The number of times participants mentioned specific nodes were counted and individual attention to the descriptions of these nodes was also considered.

\section{RESULTS AND DISCUSSION}

\section{Ethnographic Description of the CBE}

On Playa Rincon, the shoreline is mostly free of permanent constructions or semi-permanent beach equipment. The shore can be accessed via boats from nearby communities or through a dirt road running uninterrupted along the beach. At the beach west end, there is a small, open-air and crudely constructed, community restaurant that 
is operated and shared among 14 local cooks. They are organized into an asociacion, which also includes a handicraft stand, small boat tour operator and kayak rentals, a low density of beach chairs rental, a table under a tree selling coconut drinks, and coconut bake goods vendors walking along the beach (Figure 2). Visitors to west Playa Rincon tend to be mainly national and independent international tourists. A small, old wooden fishing boat with paddles is beached near the restaurant. Exempting the community restaurant, there are no other structures on west Playa Rincon.

The opposite east end of Playa Rincon has an old cement house now functioning as a very basic beachside restaurant. For example, all of the fish are local and cooked over charcoal and there is no inside seating, only an open-air patio. Near the old house is an open-air, thatched restaurant. The restaurants on this side of the beach try to provide and maintain a more aesthetically pleasing environment for their "higher-end" international clients on group tours. There is an enterprise providing massage services under a wall-less hut, plenty of rental beach chairs at a higher density along the shore, a kayak and snorkeling rental station under the trees, and another independent shack selling drinks (Figure 2). Roving the area are some handicraft vendors and a local spear fisher.

These small-scale entrepreneurs along Playa Rincon are at the low-mid stages of the CBE. The space enclosed by local entrepreneurs is minimal since there is only a small restaurant installation, artisanal fishing, and a low-density beach chairs on the shore. West Playa Rincon falls in level two to four on the CBE. The middle of the beach contains no installations or economic activity, reflecting level one on the continuum. Enterprises on the east side attract large groups from Punta Cana, occupy a larger area 
per enterprise setting the area slightly up on the CBE. However, at this fifth stage on the continuum, obstruction of beach access and negative effects on the local community is relatively small, though visible by the increasing segmentation of east and west Rincon.

According to the TALC model, the empty middle section of Playa Rincon is in its exploration stage: an area of limited and sporadic visitation by adventuresome tourists (Butler, 1980; Douglas, 1997). This initial stage of the TALC provides minor social and economic impacts, despite a high degree of contact with locals (Butler, 1980). While west Playa Rincon maintains some characteristics of the exploration stage, this side more appropriately fits the description of the involvement stage. The second stage of the TALC is defined by increasing visitation and the presence of some tourist services provided by locals (Butler, 1980). At this stage, contact between visitors and local inhabitants is high and increases for those local providing services (Butler, 1980). East Playa Rincon resembles some of the characteristics of the stage of involvement, but also a slightly early development stage. The development stage is characterized by investment on more elaborate, up-to-date facilities catering mainly for tourists (Butler, 1980). Local facilities unable to provide a more modern, aesthetically-pleasing environment disappear and organizations outside the tourists destination become more predominant (Butler, 1980). While investment from organizations in this side of Playa Rincon has not yet occurred, the area is experiencing further growth in visitor numbers, local services focusing on upscale tourists, and the creation of a more commercial structure limiting informal relationships with tourists.

Playa Grande initially displays similar organization and economic activities as Playa Rincon. At the entrance of the beach, there is a large parking lot with a relatively 
bigger wooden shack restaurant, called Blue Restaurant, which is also communal in nature shared by 16 cooks. This group of cooks is also organized into an asociacion and uses a rotatory shift schedule with half of them working every other day. Westward from Blue Restaurant, there are about 32 boats stationed along the shore use for daylong boat tours to nearby beaches. Next to Blue Restaurant, there is a long table stand selling handicrafts, beach chairs for rent along the shore (in small density, though it feels crowded with all of the surrounding activity) and a small, relatively new beach kiosk, called Sunrise Bar. This bar has a more sophisticated look and an ampler variety of drinks marketed at higher prices, which attracts a more upscale clientele.

A wooden house near the middle of the beach hosts five entrepreneurs, who are part of Asociacion Maya. Further east, there is another entrepreneur stationed under a tree selling tours, who shares that area with local fishers who maintain their four wooden rowboats near. Tourists from the all-inclusive resort must transit the area shared by fishers and enterprises along the shore to visit town. The resort and hotel caters primarily to European and North American clients (Skoczen, 2008). Even though the Dominican Constitution guarantees access to the shore, an armed guard stands at either end securing the resort beach entrance. The hotel provides a bar and restaurant for its clients, as well as kayak, snorkeling, beach chairs, and sailboat rentals. There is also an air-conditioned hotel-run gift shop and a hotel-affiliated, somewhat independent, scuba diving center and daylong tour operator on the beach in front of the hotel providing the same trip packages as the local tour operators near town. Only a small group of local vendors wearing an official uniform with an ID card are permitted to rove around the hotel beach and sell daylong tours and handicrafts. 
The latter half of the CBE is observed on Playa Grande where high density of enterprises and a resort are seizing a significant portion of the shore. Along Playa Grande, there are pockets of the coastline that have been enclosed by various smallscale enterprises, which provide convenient services but also limit recreational access. The resort beach, though theoretically free for everyone, is policed by private guards and dominated by foreign tourists to the point that it can be considered fully or semiprivate. On Playa Grande, stages five to eight on the CBE are vividly observed, but lower stages can also be noticed.

The TALC model firmly places Playa Grande in the development stage. On Playa Grande, local facilities are continuously facing potential or actual displacement by more elaborate and modern ones. Here, local participation and control of the shore is shrinking, a number of villas, hotels and foreign-own restaurants around town compete with the local facilities to take advantage of the rapidly growing tourism industry. In the development stage "local involvement and control of development will decline rapidly" (Butler, 1980, p. 8), a noticeable trend on Playa Grande. The resort area of Playa Grande fits with Butler's (1980) consolidation stage: an area dominated by tourism, international investment, and expensive marketing schemes to attract more distant visitors.

The CBE and Effects on Coastal Communities: Initial Five Stages

Interviewed key informants and community members expressed a variety of social and economic impacts at different levels of beach enclosure. Playa Rincon illustrates stages one through five on the CBE: empty beach to areas increasingly 
specializing on international tourists. While isolated beaches are rare commodities for international tourists, they only encourage minimal social or economic activity. Indeed, the entire middle section of Playa Rincon was often unused, lacking of enterprises. Gill and cast net fishing and boat storage were the only sporadic activities taking place at these area. A Rincon entrepreneur explained that "there is nothing along the middle of the beach and people prefer to visit each end of the beach where the water is calm and there are more people" (Rodrigo, personal communication, August 2016). This view that the middle of the beach is an empty and unproductive space is shared by several other groups, including the community and visitors whom—aside for the selfies and short walks—rarely spend much time on these unfrequented areas. Dominicans are highly social and enjoy being around other individuals, hence, even local residents prefer to congregate at either end of Playa Rincon. A national tourist explained that Dominicans like to visit these areas "because of our customs... it is true that we sometimes want to stay away from people [on the beach], but there are times that we miss interacting with people" (Sandoval, personal communication, August 2016). These empty shores are perceived as having low economic value for locals that cannot yet build any viable form of economic activity. Empty areas are also of less social value to the community that prefers more populous portions of the shore.

Visitors and locals alike congregate around each end of Playa Rincon where small-scale economic activity and some enclosure are occurring. This preference was also observed on Playa Grande. Observational data and all 48 participants stated most visited areas correlate with areas near restaurants and other businesses where essential and new services are available. An international tourist stated, "I only go to the 
east side [of Playa Rincon] and these restaurants with my tour" (Porta, personal communication, August 2016). "Tourists like to come here [to west Playa Rincon] for the nice beaches and because they know that they can find food and drink right here at our businesses," added an entrepreneur (Luisa, personal communication, August 2016). Statements like these were common among all 48 participants when describing their most visited area on the beach, which was relatively near to beach enterprises. These results suggest that small enclosures of the beach, as opposed to empty beaches, are more desirable for visitors and more profitable for locals. Such enclosure, in the initial four levels of the $\mathrm{CBE}$, enhances the social value of the beach for the community and visitors by providing a more desirable recreational space with a variety of services for all to enjoy.

At these small-scale enclosed areas, the ability for foreign-local interactions and exchange of ideas is greater, than on areas higher on the continuum. Silvia, working in west Rincon, said:

Here I have met many people from all over the world and learned a lot about how people from distant lands are. Many of my clients from other countries become friends who come to visit us every time they are in the country and tell me stories about their lives and family. I also tell them about my life and family (personal communication, August 2016).

These four stages of the CBE are similar to the exploration and involvement stage of the TALC model where contact between tourists and local residents intensifies for those locals involved in tourism (Butler, 1980). In contrast, east Playa Rincon, which at level five on the $\mathrm{CBE}$, is already experiencing limited interactions with international tourists, despite a higher volume of visitors. East Rincon receives mostly daytrip international tourists in all-included tours of 30 to 200 or more travelers. East Playa 
Rincon's focus on international tourists is welcome by enterprises, although greatly reduces the tourists-local interaction. The owner of various enterprises in east Rincon explained:

I don't interact much with the [international] tourists. I have more contact with the taxi drivers and tour guides than the tourists because the tourists mostly keep to themselves and their group (Diego, personal communication, August 2016).

Observational data supports this trend given how visibly intermixed the local, national, and international visitors are on west Playa Rincon, a dynamic which is almost non-existent on the east side. The TALC model supports these observations regarding reduced interactions in the progression of the $\mathrm{CBE}$. A shift from the involvement stage to the development stage reduces the interaction between local inhabitants and visitors (Butler, 1980), which is the case in Rincon. These divisions between east and west Playa Rincon institute a shift from open social space to space that is closed to the group or even couples or families who do not even interact with people on the neighboring beach chair-yet alone the locals. These examples underline the subtle, though growing divisions that are created as enclosure of the shore increases on the CBE. At these stage, the economic benefits derived by the community from the beach might be increasing, however, the social benefits are showing troubling signs of decline.

Areas of near or full enclosure, such as resorts, the social exchange between locals and foreigners is greatly limited. A guest at the all-inclusive resort on Playa Grande explained:

Honestly, I only interact with the people I know and some other French tourists I have met here in the resort. I don't really interact with locals; I don't even see them in this beach... maybe [local] people are not authorized to come here (Francois, personal communication, August 2016). 
The response of all seven tourists staying in the resort complex aligns with the above comment regarding low levels of interaction with non-resort guests. According to the TALC model, a common occurrence in the consolidation state is "some deprivation and restrictions" on the local way of life (Butler, 1980, p. 8). These findings signal that increasingly higher levels of enclosure are not conducive to social exchange between the local and international population as the community is gradually excluded from the shore.

In addition to these social implications, there is an array of economic benefits and consequences at each stage on the CBE. Among the most notable effects is the increase in economic activity along the CBE. Upsurge in beach visitors generate new small-scale economic opportunities for local communities. One entrepreneur on west Playa Rincon explained this process:

When I started working on the beach, I was the only business here... then this asociacion was formed and about 14 other women started to sell food on the beach. It included people selling drinks, the beach chair business, the handicraft [stand], and other people selling other things that joined later (Nadia, personal communication, August 2016).

Like the CBE model, Butler's (1980) model also indicates an increase in visitation and economic activity for local residents in the first two stages of development. Interviews with Playa Rincon entrepreneurs demonstrate that increase visitation without enclosure generates opportunities for small-scale entrepreneurial activities. Studies in several developing countries have also showed that various forms of tourism-related business activities are created after the arrival of visitors in new destinations (Dahles \& Bras, 1999). Additionally, the lower stages of the CBE are more receptive to new entrepreneurial activity, both in terms of abundance of business opportunities and the 
cost associated with starting an enterprise at different stages of enclosure. On Playa Rincon, for instance, west businesses totaled 32 small, independent enterprises, while the east side only accounts for 18 enterprises. Hence, while more income is generated on the east side, that income is concentrated in fewer people. Thus, concentrated entrepreneurial activity among fewer community members limit economic prospects for Rincon residents.

The CBE, Different Forms of Capital, and the Last Three Stages

Along the $\mathrm{CBE}$, there are different levels of enclosure pursuing various stages of development, i.e., as the beach uses move from open access to completely captured by capital—and in this case, foreign capital. It was hypothesized that different forms of capital would be required to enclose the shore for increasingly privatized forms of economic activity. The following section presents results about the various type of capital required for enclosure, giving emphasis at the last three stages of the CBE where the influence of foreign capital is most noticeable.

On Playa Grande, most enterprises along the beach share many characteristics of Rincon businesses, but also exhibit the last three stages of the continuum. Like Rincon, growth in tourist visitations has generated of a variety of small-scale enterprises. Some of these independent enterprises are situated along the low-mid stages of the CBE catering towards national as well as international visitors. However, having such proximity to the resort, a variety of entrepreneurial services are tailored to the demands of the higher paying tourists, most notably the tour operators and the new Sunset Bar. 
Scientific research on social capital and entrepreneurship has confirmed social capital as a noteworthy factor in determining the establishment and success of new enterprises (De Carolis \& Saparito, 2006). Other studies in developing countries demonstrated that social capital is instrumental in the formation of new economic activity (Jones, 2005). Although Playa Grande has a higher abundance of small-scale commercial activity, the cost of creating enterprises on Playa Grande is significantly higher than Playa Rincon. All 11 interviewed entrepreneurs from Playa Rincon reported needing minor economic capital to start and conduct economic activity. "I began my business with a small wooden desk on the beach... to start I didn't need much money, nothing actually. I didn't buy anything since I made all the products myself from easily accessible material," explained a Rincon entrepreneur (Primo, personal communication, August 2016). On Playa Rincon, social capital is an important component for conducting entrepreneurial activity. Most enterprises on Playa Rincon admitted having relied on their social capital, receiving help from family, friends, and asociacion members, to establish and run their beach enterprise. "My son and husband would catch the fish right there on the beach, so I didn't have to buy them... I would also borrow any additional food and seasoning from the small market in town" claimed a businesswoman from west Rincon (Silvia, personal communication, August 2016). It is necessary to note that borrowing food products, gas or money is a common practice among entrepreneurs and the community. However, borrowing is possible because of social expectations and pressure to repay, as there is no collateral required between the lending and borrowing party. An entrepreneur providing massage services added, "[C]onstructing this hut where we work was a collective effort. Luna and some of the other guys working here 
[on the beach] helped us" (Lady, personal communication, August 2016). The construction of the communal restaurant on west Rincon was accomplished through the "asociacion members' collaboration," said Rodrigo, president of the asociacion (personal communication, August 2016). These statements from Playa Rincon entrepreneurs substantiate the importance of social capital for creating and maintaining enterprises at lower stages of the CBE.

In contrast, Playa Grande entrepreneurs required more financial investment to enclose the shore and carry out economic activity. Sevilla-Buitrago (2015) investigation of enclosure's long-term historical and geographical perspective demonstrates the inherent links between capital and the creation of enclosed spaces. He describes enclosure as "a prominent territorial feature in the longue durée of the capitalistic mode of production of space" (Sevilla-Buitrago, 2015, p. 1001). Sevilla-Buitrago (2015) argues that, "[a]s was the case with markets or wages, enclosure predated capitalism but acquired a structural regulatory role in the advent, consolidation and subsequent development of the new sociospatial formation" (p. 1001). Sevilla-Buitrago sustains that "[e]nclosure constitutes a key step in the homogenization of space, e.g., the tendency to normalize space under a unitary political-economic rationale" (2015, p. 1001). SevillaBuitrago (2015) suggests that enclosure is used to "designate capitalism's mobilization of diverse configurations and significations of space to deprive people of what they create in common" (p. 1000). The researcher goes further into calling this form of enclosure through the movement of capital a new "global land grab" (Sevilla-Buitrago, 2015, p. 1007). In the more developed Playa Grande, the manifestation of economic capital as a leading engine to fabricate enclosed spaces for business activity is quite 
noticeable at the small and local scale, but more noticeable at large-scale, international resort development.

Two out of the nine entrepreneurs on Playa Grande reported to have needed significant economic capital to start their small enterprises. Over half of Playa Grande entrepreneurs voluntary indicated that to establish an enterprise on Playa Grande it is more expensive now as compared to the time when they started their business on the beach many years ago, even after adjusting for inflation. This is partially attributed to well-established and dense networks of asociaciones that now impose more obstacles, including higher entrance fees, for new entrepreneurs in an attempt to discourage the creation of new enterprises in an already densely competitive market. Asociacion fees are use to maintain a clean and healthy beach, help provide a secure environment for visitors, pay for maintenance and organization of communal working areas, and other services that are seen as beneficial for the entire community.

The following case between two entrepreneurs in each study site illustrates the disproportionate cost of conducting economic activity at the more developed Playa Grande. An entrepreneur on Playa Grande reported to have obtained a bank loan of US\$8,000 (DR $\$ 266,496)$ to create a boat tour company for transporting tourists to nearby beaches. This entrepreneur attributes the high cost to his expensive business equipment (which is needed to appeal to international tourists), but also to the payments he had to make to join the existing boat union. These payments are negotiated on a case-by-case basis, depending on location and levels of development, since large asociaciones that are trying to limit competition tend to charge higher fees. Such initial costs range from USD $\$ 100(\mathrm{DR} \$ 4,550)$ and US\$1,000 (DR $\$ 45,5000)$ or more. In 
Franco's case, he joined the asociacion when there were over 20 competing boat enterprises, which meant paying higher fees. Consequences for failing to join an asociacion include social repercussions such as animosity and constant complains towards the newcomers from existing entrepreneurs trying to maintain the status quo. Asociaciones also exert pressure on local authorities to decommission any improper shoreline structures. On August 2016 a local entrepreneur reported that after a dispute with the Maya Asociacion president, he decided to leave the asociacion and slowly built a bar on the shore. Later that day, this entrepreneur recounted that the local police had evicted him from the beach and confiscated all of his small equipment and other personal belongings. When this individual complained to the Maya Asociacion, he was told to seek help from the Samaná Governor since at that point only higher levels of political support would make a difference. Lacking enough resources and political capital, this entrepreneur was forced returned to the asociacion.

Contrary to Franco's enterprise, on Playa Rincon, an entrepreneur reported to have started a similar boat tours enterprise for only US $\$ 420(\mathrm{DR} \$ 14,000)^{1}$. Rodrigo's boat, however, is much older and non-motorized, which limits it to short distance tours around Playa Rincon only. His small boat tour enterprise is the first of its kind in less developed Playa Rincon, which allowed him to cheaply join West Rincon Asociacion. Rodrigo's rowboat business model, while working perfectly at Playa Rincon, cannot compete on Playa Grande because the already competitive market demand for faster, more reliable boats-which require higher economic capital investment. Rodrigo relied on his social capital to pay for his investment, not a bank. Rodrigo reported borrowing

\footnotetext{
${ }^{1}$ Currency conversions were made based on 2006 official exchange rate data from the
} World Bank. 
US $\$ 270(D R \$ 9,000)$ from his friend and the remaining US\$150 (DR $\$ 5,000)$ from his family. Both boat enterprises enclose a small portion of the beach and started within the last ten years, however, the Playa Grande enterprise cost 19 times more.

Similarly, restaurateurs at the communal restaurant on Playa Grande and Playa Rincon reported paying significantly different amount of money to start their enterprises. Nadia from Playa Rincon and Yasmin from Playa Grande started by setting up a small hut on the beach and have been selling traditional Dominican seafood for 30 years. Yasmin reports to have spent about US $\$ 1,722(\mathrm{DR} \$ 5,000)^{2}$ on her restaurant. She attributes the cost to start her enterprise to the equipment, purchasing produce and seafood, and transportation. Inversely, Nadia on Playa Rincon said to have only needed US\$344 (DR $\$ 1,000)$ or less to start, since her husband would fish and grow the agricultural products she needed. These two restaurateurs provide the same services and enclose an equal beach space, however, the Playa Grande enterprise cost five times more. These examples demonstrate how more developed and exclusive portions of the shore require more economic capital to enclose equal shares of the beach. The TALC model support these observations since areas in the development stage often require "larger, more elaborate, and more up-to-date" equipment and facilities (Butler, 1980 , p. 8). These results suggest that the progression on the CBE reduces the capacity of community members to enter the tourism market as the cost to start an enterprise on the beach increases. More vivid effects regarding the power of capital to homogenized space for international travelers are exhibit on resort areas, which is later discussed.

${ }^{2}$ Currency conversions were made based on 1986 official exchange rate data from the World Bank. 
Political capital is fundamentally linked with economic capital in their efforts to mold the common shore into a highly developed and private area. Sevilla-Buitrago argues that a new global land grab "involves the penetration of corporate investorsusually governments and firms, sovereign wealth funds and investment banks—in foreign countries in Africa (Makki 2014), Asia (Hsing 2010: 181ff.; Levien 2012), Latin America (Borras et al. 2012) and the former Soviet Eurasia (Visser and Spoor 2011)" (Sevilla-Buitrago, 2015, p. 1007). Sevilla-Buitrago recognizes that the role of developing nations as facilitators in the enclosure process is vital. The actions of developing countries are taking to facilitate the penetration of capital for the purpose of enclosure range from: "the implementation of investment-friendly legal and fiscal frameworks, to activate involvement through expropriation and eminent domain, to the building of support infrastructure and other projects" (Sevilla-Buitrago, 2015, p.1007). The DR government has implemented many of these actions in favor of foreign capital development. Vergara's (2004) analysis of the historical presence of foreign capital in the DR shows that a culmination of various economic reforms and policies, carried out by the government since the 1970s, has consolidated the country's standing as the principal recipient of foreign investment by the early 2000s. Based on the study of Borras et al. (2012), Sevilla-Buitrago (2015) postulates that the penetration of capital in less developed areas of the world is rather strategic. "As was the case with English enclosures, the state's bending of regulatory simplification, sovereignty and coercion eases the entry of capital in strange territories that usually lack preexisting formal land rights or include abundant forms of communal tenure" (Sevilla-Buitrago, 2015, p. 10071008). This comprehensive theoretical analysis demonstrates the relationship between 
various forms of capital and enclosure, as well as the active role of the State and political capital to allow the seizure of land by wealthy international investors.

Examples of this link between political and economic capital in the DR are neoliberal policies created as political initiatives driven by economic influences and desires (see Mitchell, 2009; Duffy et al., 2016). Political capital, however, is not equally salient throughout the CBE. The salience of political capital, however, varies greatly depending on the level of development an area is experiencing. At the less developed Playa Rincon, nine out of 11 entrepreneurs who commented on economic capital noted that political capital was not necessary to start their enterprise. Since Rincon lacks coastal infrastructure development, large developers provide neither opposition nor competition to current small-scale economic activity. The lower stages of the CBE represent least developed areas, where political capital is less salient. Playa Grande enterprises started at a time when the beach was less developed demonstrate how unnecessary political capital is at such early stages. Seven out of nine entrepreneurs from Playa Grande who started their enterprise at least over a decade ago said that political capital was not an important contributor to establishing their enterprise. To illustrate this point, an entrepreneur explained, "No, when I started I did not need political help because when the beach is pristine and there is not much development, you do not need political help" (Roberto, personal communication, August 2016). Assertions from these Playa Grande entrepreneurs substantiate that political capital is not necessary to conduct economic activity at lower stages of the CBE.

However, as Playa Grande advanced up the CBE and further developed in recent years, the need for political capital has increased. Two new entrepreneurs on 
Playa Grande reported to have started their enterprise using political help. One of them said that while asociaciones and beach entrepreneurs opposed having another enterprise on the shore, the Samaná governor provided significant support. "If I didn’t have the political support from the Samaná governor, I wouldn't have been able to start this business," said the new entrepreneur (Jesus, personal communication, August 2016). The governor assistance consisted of written legal permits and delegations with the regional Dominican Navy and Ministry of Tourism representatives to allow for the uninterrupted operation of Jesus's beach bar. In this example, political power of higher levels of government, such as the governor, allows to easily create new forms of economic activity along the beach, which underlines the shifting nature of capital as social capital is superseded by political capital when the beach progresses on the CBE. Other research participants also contributed evidence supporting the prominence of political capital in more developed areas. Eight key informants unprompted claimed that political capital is increasingly vital for new small-scale enterprises on Playa Grande. The salience of political capital is a result of a large volume of enterprises on the beach that have driven up the costs of asociaciones membership and created much competition. Additional competition from resort enterprises is also a contributing factor to higher costs for new enterprises. As a result, most establishments and asociaciones on Playa Grande are opposed to creating new coastal enterprises. An entrepreneur explained, "No, you—even current members of the Asociacion—cannot start more businesses selling food here. We are already too many businesses selling food, 16 of us, so there is no room for others to join" (Trina, personal communication, August 2016). This sentiment is shared among most entrepreneurs with immediate and strong 
opposition to additional economic activity and competition on the shore. Because of this opposition, new entrepreneurs on Playa Grande are increasingly utilizing political capital, as it becomes the only means to create a new enterprise on the shore. Thus, the reliance on political capital has potential impacts on the broader community of Playa Grande that lacks access and resources to obtain political support. Hence, the majority of the community's capacity to establish an enterprise in the common shore is hampered.

At the last stage on the CBE, highly exclusive resort development demands higher levels of economic and political capital, often far out of the reach for the local community. A total of 34 participants indicated that large amounts of economic and political capital were essential, indeed almost synonymous with large-scale enclosure and developments such as resorts. According to key informants and other interviewees, to conduct economic activity, at the scale of the resort on Playa Grande, large economic capital investment is non-negotiable. A community leader and architect from Playa Grande said that the amount of investment for such "large projects requires exceptional amounts of financial resources" to cover all costs for purchasing land, surveying, planning, taxes, 'political friendships,' and construction (David, personal communication, August 2016). Small-scale businesses, such as Jesus' beach bar, also have access to political capital, although, millions of U.S. dollars are not required. Strong social status and family relationships with political leaders, plus a few thousands of Dominican dollars, is more than enough to obtain political favors for small-scale economic activity, affirmed David and other key informants. According to David and all other 33 participants that commented on the resort on Playa Grande, the investment and money 
generated at this locale belongs to foreign investors. The accounts of multinational investment in large-scale tourism development is well understood in the DR (e.g., Roessingh \& Duijnhoven, 2005; Sambrook et al., 1992; Sasidharan \& Hall, 2012).

As economic capital becomes more important for large-scale development at the far end of the CBE, the salience of political capital also increases. Sevilla-Buitrago's (2015) analysis of role of economic capital and national governments in developing countries play in enclosing common spaces is particularly applicable to large-scale development at the last stages of the CBE. A local government official said, "Political influence is needed for any large project. Here, in the county, nothing gets done without help from politicians" (Paz, personal communication, August 2016). These and similar statements were mentioned by all participants that discuss the use of political capital for enclosure. The larger the project and enclosure, the more important political capital becomes. According to the town architect on Playa Grande, for an all-inclusive hotel constructed along the beach, it would require to "go to a senator and obtain their support to convince the president to provide authorization for such projects" (David, personal communication, August 2016). Another government official added that legally any form of construction on the public beach is not allowed unless a "presidential decreed is obtained" (Carlos, personal communication, August 2016). The Dominican law specifies that only the president holds the power to authorize the construction along the common shore for the "purpose of tourism" development and other public benefits (Law No. 305 of 1968, Art. II). These statements and the structure of the law in the country suggest that for large developments at the last stages on the continuum political capital is evermore vital. 
This case study in the DR corroborates Sevilla-Buitrago's theory-testing research regarding the active role of capital in enclosing the commons. Study findings showed how political capital and economic capital often collaborate in their efforts to obtain control over the shore. Undoubtedly, as an area advances on the CBE and becomes more developed and exclusive, economic capital is increasingly essential and political capital replaces social capital in importance for conducting economic activity. Stage five and above on the CBE provide increasingly fewer opportunities for the creation of independent economic activity capable of sustaining entire families. At the last stage, highly developed resort complex obtain full control of the shore and the economic activity on the area, limiting opportunities for communities. These observed impacts of the CBE are substantiated by similar trends described in the TALC model.

The CBE: Resorts Impacts on the Community

The development of beach resorts areas has other direct social implications for local communities. At lower stages of the $\mathrm{CBE}$, the coastal community utilizes the beach for subsistence, recreational space, and economic activity. Though subsistence fishing was a minor focus in this study, such beach use was a fundamental aspect of the lives of interviewed fishers. Fishing on Playa Rincon and on segment of Playa Grande is a vital livelihood. The large-scale resort on Playa Grande drastically reduces and interrupts small-scale economic activity, fishing, and recreational access to the shore. Chico, who has been fishing on Playa Grande for over 45 years, explained that "in the past, we spent lots of time there [on the resort area]. We used to go to catch crabs, large fish, and smaller fish for bait, too... Now, there is nothing there for us, only tourists 
and hotels" (personal communication, August 2016). Playa Grande and other regions are examples of consequences originating from losing access and total disruption of the previous beach uses. In the Punta Cana region, larger resort development projects constructed in the 2000s displaced an entire coastal fishing community and later restricted their access to the shore, creating major social and economic disruption to the community (León, 2007). As these large projects have the potential capacity to displace entire community groups from accessing an essential and emotionally valuable part of the beach, people in the studied sites expressed concerns. Silvia, who lives and works at Playa Rincon, said the construction of an exclusive hotel on Rincon would be traumatic "for everyone in the community who has lived and grew up on this beach" (personal communication, August 2016).

Other coastal residents voiced their concerns regarding large-scale tourism development and the potential impacts on their way of live. Negative attitudes towards the impact of large-scale tourism were shared among 15 entrepreneurs who discussed the implications of development. On Playa Grande, Yasmin said: "tourism benefits [for our small restaurant business] have decreased now that there are more hotels and restaurants everywhere. This [competition and form of tourism] brings us less clients because the tourists never leave their hotels and the restaurants there" (personal communication, August 2016). Another entrepreneur working next to the resort added, "We see more tourists, but the tourists that come to these hotels do not spend money at our business since they have the all-inclusive hotel" (Tracey, personal communication, August 2016). Seven international tourists staying at the all-inclusive hotel supports these statements. Among these tourists is Ted, who said, "I don't even leave the resort 
area... [W]e get everything from the resort" (personal communication, August 2016). These accounts reflect the shifting economic dynamics on Playa Grande where largescale tourism development is competing and replacing the local, small-scale economic activity.

Other studies in the country have highlighted the impacts of profit leakage, social and economic exclusion, and other socioeconomic problems for the local community resulting from large-scale resort development in regions like Punta Cana and Puerto Plata (Cabezas, 2008; Duffy et al., 2016; Roessingh \& Duijnhoven, 2005). In the case of Puerto Plata, large resorts development occurred in the early 1980s, yet over 30 years later most local entrepreneurs have not seen enough benefits (Roessingh \& Duijnhoven, 2005). The last stage on the CBE, as demonstrated in this and other regional studies, is an arena where large, multinational capitalistic tourism installations compete with the local economy and limits the growth and development capacity of local entrepreneurs. These same local effects presented via CBE model are substantiated by the TALC model, which postulates a rapid decline in local involvement and control after the development stage.

Furthermore, some of the applauded benefits of such large projects are the capacity to generate jobs, although even this benefit does not seem to provide sufficient gains for Playa Grande residents. A community member said that "I have a sister that works at the [all-inclusive] hotel... but the company does not have as many jobs during the low tourism season, so my sister and other workers are always unemployed during that period" (Alma, personal communication, August 2016). A government official adds, "Our experience with these projects tells us that practically all negative consequences 
are for the community... the biggest hotels in town, for instance, pay so little that every person that ever works there doesn't want to work there again" (Geremia, personal communication, August 2016). These accounts dispute the idea that large-scale projects bring economic prosperity and good paying jobs. Similar contradicting results regarding resort job creation have also surfaced in other regional studies in the DR and the Caribbean where low-paying jobs in the formal sector compare to neo-colonialism forms of servitude (Cabezas, 2008).

While a variety of socioeconomic problems are observed at higher stages of the CBE, low-mid stages of the continuum preserved local social structures. On Playa Rincon, small-scale economic activity is sustained and improved with slightly more exclusivity, though opportunities for new enterprises are constricted as areas begging to cater to international tourists. On Playa Grande, local economic activity is also uninterrupted with some level of enclosure. Subsistence fishing is undisturbed, instead the small scale-economic activity and tourists support fishers as the fish are sold and consumed directly on the coast. At low-mid stages of the CBE the economic pie is shared within the local community. Mitchell and Reid (2001) demonstrated the socioeconomic benefit of tourism to a rural Peruvian community, at the small-scale. Other studies also attribute the benefits of tourism development, at lower stages on the continuum, in areas such as improving local education, health, and increase in selfesteem within the community (Scheyvens, 1999). Different states on the CBE, which are influenced by social, economic, and political capital, generate various forms of social and economic opportunities for coastal communities. The last stages on the 
continuum, however, certainly provide significant constraints to the local entrepreneurs and community.

\section{Addressing Power Imbalances Via Community Referenda}

The shores of Playa Grande and Playa Rincon are vital social and economic spaces for the people living in these communities. If political and economic capital manage to fully capture the shore, the socioeconomic ramifications to residents of these coastal communities would be shocking. Therefore, to maintain some level of local jurisdiction over the beach and prevent the invasion of foreign economic and political capital in these two localities, the local community and entrepreneurs of Playa Rincon and Playa Grande need to wield and sustain more control over the shore. Ensuring these communities preserve authority over the shore could be done through enacting a referendum of approval where the community and entrepreneurs enjoy the power to approve or disapprove new development projects. Such a referendum would provide an initiative to increase the participation of the local community in the decision-making process in tourism development, which is a priority for communities in developing tourism destinations (Michael, Mgonja, \& Backman, 2013). This new local policy could help ensure that foreign capital and political capital does not overpower the needs of the local community. The community referendum approach would grant more authority to the community in an attempt to balance the power inequities created by the percolation of foreign capital and its political influence in the region. Mcgee (2009) describes the power of the community referendum as a right for local communities experiencing different waves of and pressures from development. Mcgee's (2009) study 
demonstrates the practical use of community referenda on mining projects where indigenous communities in Latin America utilized this tool to oppose undesirable mining projects. This case is unique because the 2007 UN Declaration of Rights of Indigenous People grants them some level of land tenure over their local territories (Mcgee, 2009), but such tenure is not guarantee for people using the common shores in the DR. Nonetheless, the indigenous case provides an example highlighting the importance of a community referendum to contest international development. The success of a community referendum to halt powerful, multinational mining companies and national government initiatives suggests that a similar approach to dealing with influential tourism development could be effectively undertaken in Samaná.

In the DR, such a referendum system is not a novel idea. All over the country a similar system is already in place. On Playa Rincon and Playa Grande, a system of asociaciones already approves and disapproves the creation of new small-scale economic activity. This system has been successful at maintaining local order and prosperity. The local authorities need to give more legal power to the asociaciones system and expand the power of these organizations so that they are able to have a tangible input in the approval of new large-scale projects that would inherently affect them first. This asociacion model, however, should not be constrained to the power of beach entrepreneurs. The new referendum of approval system should incorporate an appropriate number of vetted representatives and leaders of each community. Ideally, the combination of entrepreneurs and community members would provide local inhabitants of Playa Rincon and Playa Grande with the necessary tools and power to defend against the new global land grab perpetuated through capital and political 
power. This new system would give entrepreneurs and the local community negotiating power for compensation in cases where large development interrupts social life, fishing, or small-scale economic activity on the shores of Samaná.

\section{CONCLUSION}

At the outset, this study began by asking what are the processes that lead to beach privatization and the socioeconomic implications of different stages of enclosure for communities in Samaná. The study showed how different forms of capital are utilized at various levels of the $\mathrm{CBE}$ as leading forces to facilitate the creation of a variety of enterprises privatizing small and large shares of the shore. Social capital was shown to be an important component in the lower levels of the CBE to generate enclosed spaces used for small-scale economic activity. However, as the levels of enclosure and development increase and the beach uses and services become gradually tailored towards upscale tourists, economic capital becomes essential to fabricate enclosed areas and political capital increasingly replaces social capital. As these forms of capital are required to establish a beach enterprise, a large segment of the local community is unable to obtain enough economic or political capital necessary at higher levels on the continuum. In this manner, the broader community is often excluded from joining the market and making a livelihood from tourism. A community referendum system is suggested as a prescriptive point of intervention allowing the local community to maintain social capital, local control of the shore, and prevent the supremacy of economic and political capital to overrun the region. 
Findings also revealed that at level one through four on the $\mathrm{CBE}$, the progressive establishment of essential and new services enhances the social and economic value of the shoreline. An increase in arrivals of tourists leads to an increased in new small-scale entrepreneurship; however, after level five on the continuum, accessibility to entrepreneurial activities declined as ownership becomes concentrated among few entrepreneurs. At level five and above, a significant portion of the community is barred from joining the beach tourism market as it becomes more costly to conduct economic activity in more enclosed and developed areas. The uses of the coast and services by the community are also reduced. Progressively, the last stage on the continuum, marked by exclusive resort developments, provides some employment opportunities for the community, but a vast array of negative consequences makes resort development unpopular and unsustainable in the community. Issues regarding coastal access, limitation on fishing, low-paying seasonal jobs, eradication of local-foreign interaction, and increased competition with the established small-scale entrepreneurs are among the many consequences emanating from the last stage on the CBE.

The CBE model provides a quick glimpse at the different effects of coastal privatization and development on entrepreneurs and the local community. These effects and model are parallel to Butler's TALC model. As other studies in the DR have previously concluded, resort tourism development provides the most negative impacts on the local community. Resort tourism development was necessary in the past to draw foreign investment, develop basic infrastructure, solidify the country standing as top tourism destination, and advance the national economic development. However, now that the DR is a leading tourism destination an upper mid-income and thriving economy, 
the country needs to shift its vision of development and emphasize small community and regional development prioritizing the wellbeing of the underprivileged segments of the population that have been previously marginalized by the national focus on resort development. As a result, a wholesome tourism vision for the DR could bring the necessary changes for a long-term sustainable development strategy that is conscious and inclusive of regional communities when creating tourism planning and policy. 


\section{REFERENCES}

Bernard, H. R. (2011). Research methods in anthropology: Qualitative and quantitative approaches. Rowman Altamira.

Borras, S. M., Franco, J. C., Gómez, S., Kay, C., \&amp; Spoor, M. (2017). Land grabbing in Latin America and the Caribbean. The Journal of Peasant Studies, 39(3-4), 845-872.

Brown, K. M. (2006). The role of moral values in contemporary common property enactment. Norsk Geografisk Tidsskrift - Norwegian Journal of Geography, 60(1), 89-99.

Butler, R. W. (1980). THE CONCEPT OF A TOURIST AREA CYCLE OF EVOLUTION : IMPLICATIONS FOR MANAGEMENT OF RESOURCES. Canadian Geographer, $\mathrm{XXIV}(1), 5-12$.

Butler, R. W. (2011). Tourism area life cycle (Vol. 20). Woodeaton: Goodfellow Publishers Limited.

Cabezas, a. L. (2008). Tropical Blues: Tourism and Social Exclusion in the Dominican Republic. Latin American Perspectives, 35(3), 21-36.

Caffrey, P., Kindberg, L., Stone, C., Torres, R., \&amp; Meier, G. (2013). Dominican Republic Climate Change Vulnerability Assessment Report. Usaid, (September).

Caribbean Tourism Organization. (2015, June 19). "Latest 2014 Arrivals Tables." Retrieved from www.onecaribbean.org/wp-content/uploads/May7Arrivals2014.pdf

Dahles, H., \&amp; Bras, C. H. (1999). Tourism and Small Entrepreneurs. Development, National Policy and Entrepreneurial Culture. Indonesian Cases. Tourism dynamics.

De Carolis, D. M., \&amp; Saparito, P. (2006). Social capital, cognition, and entrepreneurial opportunities: A theoretical framework. Entrepreneurship: Theory and Practice, 30(1), 41-56.

di Gianfrancesco, T. (2014, December 02). Le spiagge italiane sono in svendita. La lobby dei gestori può festeggiare Retrieved from http://espresso.repubblica.it/attualita/2014/12/02/news/le-spiagge- italiane-sono-in svendita- la-lobby- dei-gestori- puo-festeggiare- 1.190170 ?ref=fbpe

Douglas, N. (1997). Applying the life cycle model to Melanesia. Annals of Tourism Research, 24(1), 1-22.

Duffy, L., Stone, G., \&amp; Chancellor, H. C. (2016). Tourism development in the Dominican Republic: An examination of the economic impact to coastal 
households. Tourism and Hospitality Research, 16(1), 35-49.

Freitag, T. G. (1994). Enclave Tourism Development. For whom The Benefits Roll? Annals of Tourism Research, 21(3), 538-554.

Freitag, T. G. (1996). Tourism and the Transformation of a Dominican Coastal Community. Urban Anthropology and Studies of Cultural Systems and World Economic Development, 25(Fall), 225-258.

García-Quijano, C. G. (2009). Managing Complexity: Ecological Knowledge and Success in Puerto Rican Small-Scale Fisheries. Human Organization, 68(1), $1-17$.

Hadjimichael, M. (2014). In Greece, a battle to reclaim the seashore as commons 46 Reclaim the Sea. Retrieved March 10, 2016, from http://reclaimthesea.org/ingreece-a- battle-to- reclaim-the- seashore-as- commons/

Heredia, F. (2009). Manejo integrado costero marino en la República Dominicana. Manejo Costero Integrado Y Política Pública En Iberoamérica: Un Diagnóstico. Necesidad de Cambio, Red IBERMAR (CYTED), Cádiz, 121-144.

Hovinen, G. R. (2002). Revisiting the destination lifecycle model. Annals of Tourism Research, 29(1), 209-230.

Johnson, J. C. (Ed.). (1990). Selecting ethnographic informants (Vol. 22). SAGE Publications, Incorporated.

Jones, S. (2005). Community-based ecotourism: The significance of social capital. Annals of Tourism Research, 32(2), 303-324.

Keul, A. (2015). The fantasy of access: Neoliberal ordering of a public beach. Political Geography, 48, 49-59.

Leon, Y. M. (2004). Community impacts of coastal tourism in the Dominican Republic. ProQuest Dissertations and Theses. University of Rhode Island, Kingstown, RI.

León, Y. M. (2007). The impact of tourism on rural livelihoods in the Dominican Republic's coastal areas. Journal of Development Studies, 43(2), 340-359.

Ley No. 305. La Gaceta Oficial de la Republica Dominicana, Santo Domingo, Republica Dominicana, 29 May 1968.

Mcgee, B. (2009). The Community Referendum: Participatory Democracy and the Right to Free, Prior and Informed Consent to Development The Community Referendum: Participatory Democracy and the Right to Development. Berkeley Journal of International Law, 27(2), 570-635. 
Michael, M., Mgonja, J. T., \&amp; Backman, K. F. (2013). Desires of Community Participation in Tourism Development Decision Making Process : A Case Study of Barabarani, Mto Wa Mbu, Tanzania. American Journal of Tourism Research, 2(1), 84-94.

Mitchell, K. (2009). Democratisation, external exposure and state food distribution in the Dominican Republic. Bulletin of Latin American Research, 28(2), 204-226.

Mitchell, R. E., \&amp; Reid, D. G. (2001). Community integration: Island tourism in Peru. Annals of Tourism Research, 28(1), 113-139.

Molina, T. (2006, April 04). Nuestras playas son propiedad privada [Our beaches are private property]. Diario Libre. Retrieved from http://www.diariolibre.com/noticias/historia-dl- nuestras-playas- son-propiedadprivada-GVDL92800

Pardilla Pino, J., \&amp; And Navarro Barber, F. (2014). Tourism and sustainable development in the province of Samaná, Dominican Republic. Investigaciones Turisticas, 8, 23-45.

Phillips, P., Russell, F. A., \&amp; Turner, J. (2007). Effect of non-point source runoff and urban sewage on Yaque del Norte River in Dominican Republic. Environmental and Pollution, 31(3/4), 244-266.

Reclaim the Sea. (2014a). Activists sue state over coast privatization (Beirut). Retrieved March 10, 2016, from http://reclaimthesea.org/activists-sue- state-over- coast-p rivatization-beirut/

Reclaim the Sea. (2014b). Protecting our shores is our right (Cyprus). Retrieved March 10, 2016, from http://reclaimthesea.org/protecting-our- shores-is- our-right- cyprus/

Ripton, John. "Developing paradise: tourism, the local community, and nature in Las Terrenas, Dominican Republic." St. Bernard's School (2013).

Roessingh, C., \&amp; Duijnhoven, H. (2005). Small Entrepreneurs and Shifting Identities: The Case of Tourism in Puerto Plata (Northern Dominican Republic). Journal of Tourism and Cultural Change, 2(3), 185-202.

Runeson, P., \& Höst, M. (2009). Guidelines for conducting and reporting case study research in software engineering. Empirical software engineering, 14(2), 131.

Sambrook, R. A., Kermath, B. M., \& Thomas, R. N. (1992). Seaside resort development in the dominican Republic. Journal of Cultural Geography, 12(2), 65-75.

Sasidharan, V., \&amp; Hall, M. E. (2012). Dominican resort tourism, sustainability, and millennium development goals. Journal of Tourism Insights, 3(1), 1-22. 
Scheyvens, R. (1999). Ecotourism and the empowerment of local communities. Tourism management, 20(2), 245-249.

Sevilla-Buitrago, A. (2015). Capitalist Formations of Enclosure: Space and the Extinction of the Commons. Antipode, 47(4), 999-1020.

Skoczen, K. N. (2008). Almost Paradise: The Cultural Politics of Dominican Identity and Tourism in Samana, Republic. Journal of Latin American and Caribbean Anthropology, 13(1), 141-167.

Syafriny, R. (2015). TRANSFORMATION AND PRIVATIZATION OF COASTAL SPACE, CASE OF MANADO COASTLINE. Journal of Human Settlement, 7(1),1021.

USAID. (2012). Programa para la Proteccion Ambiental: Caracterización Ambiental Provincia Samaná. Washington, D.C.: USAID.

USAID. (2013). USAID Country Profile: Property Rights and Resource Governance Dominican Republic. Washington, D.C.: USAID.

The World Bank. (2017). "Official exchange rate [Dominican Republic]." Retrieved from https://data.worldbank.org/indicator/PA.NUS.FCRF?end=2016\&locations=DO\&start $=1960 \&$ view $=$ chart

Van Noorloos, F. (2011). Residential Tourism Causing Land Privatization and Alienation: New pressures on Costa Rica's coasts. Development, 54(1), 85-90.

Vergara, S. (2004). La Inversión Extranjera Directa en República Dominicana y su impacto sobre la competitividad de sus exportaciones. United Nations Publications (Vol. 151). Santiago de Chile: United Nations.

World Tourism Organization. (2016). Annual Report 2015. Madrid, Spain: UNWTO. 